\title{
correspondence
}

\section{Science and politics}

I

n his 1977 obituary of Trofim Lysenko (1898-1976), the British biologist Cyril Darlington (1903-1981) commented that Lysenko was "obviously ill-educated, quite shallow, very cunning and a little deranged" (Darlington, 1977). Lysenko's rejection of Mendelian genetics in favour of Lamarckism, his embrace of the hybridization theories of Russian horticulturist Ivan Michurin (1855-1935), and his claims that plants can be heritably altered by graft hybridization or environmental conditions certainly ran counter to mainstream biological research. His influence and thirst for power had an impact on many areas of Soviet science and politics. The Soviet government imposed a complete ban on the practice and teaching of Mendelian genetics. Russian biological science, which had previously flourished, rapidly declined (Soyfer, 2001).

Lysenko was born into a peasant family in the Ukraine and achieved acclaim working as a plant biologist in the late 1920s. His pioneering work on vernalization and his claim that pre-treating seeds in such a way that the treatment's effects were allegedly 
passed on to the next generation made him the posterchild of Soviet biological research: a peasant's son who claimed spectacular success in crop science where academic scientists had failed. His popularity with the Soviet leadership and the populace fuelled his rise to power. In 1935, he started a campaign, partly scientific and partly political, against Mendelian genetics. He claimed that Mendelian laws were "scholastic" and "barren" and did not "reflect" the importance of the environment. Many of his opponents were banned from doing research, such as Nikolai Dubinin (1907-1998), the leading Soviet geneticist, who lost his academic position and saw some of his closest friends imprisoned (Graham, 1987). In 1940, Lysenko became Director of the Institute of Genetics within the USSR Academy of Sciences, where he used his political influence and power to dismiss Mendelian genetics as "bourgeois science" and "pseudoscience". Yet, even Stalin was not convinced of Lysenko's scientific and political claims. Stalin removed all mention of "bourgeois biology" from Lysenko's report, The State of Biology in the Soviet Union, and in the margin next to the statement that "any science is based on class" Stalin wrote, "Ha-ha-ha!! And what about mathematics? Or Darwinism?" (Rossianov, 1993).

In general, scientists accept a colleague's claims if they are convinced that the author is a man of integrity. Lysenko did not convince most scientists of his integrity, given the obviously emotional and political content of his arguments (Rossianov, 1993). Not surprisingly, Lysenko's theories were largely rejected outside the USSR. One of Lysenko's most outspoken critics was the East German geneticist Hans Stubbe (1902-1989), Director of the Institute of Crop Plant Research in Gatersleben, who demonstrated that Lysenko's experiments on graft hybridization were not reproducible and concluded that he was a fraud, vehemently fighting the influence of Lysenkoism in the German Democratic Republic (Hagemann, 2002).

Yet, Lysenko's work on graft hybridization is not entirely wrong; indeed, there is a possible path for horizontal gene transfer between stock and scion. Several groups of non-Soviet scientists have shown that graft-induced variant characteristics are stable and inheritable (Ohta, 1991; Liu, 2006), and most recently, Stegemann \& Bock (2009) demonstrated that tissue grafts can exchange genetic material. Lysenko, however, rejected the idea of genes as the vector for this transfer of information, writing in his 1954 book, Agrobiology, "experiments in graft hybridization provide unmistakable proof that any particle of a living body, even the juices exchanged between scion and stock, possesses hereditary qualities" (Lysenko, 1954). Even Michurin, on whose work Lysenko had built his theories, suggested that genes might move between the stock and the scion (Liu, 2006). Moreover, Lysenko neglected the great progress of genetics research outside the USSR when Oswald Avery and his co-workers showed that DNA is the hereditary material in 1944, or when Francis Crick and James Watson unravelled the structure of DNA in 1953.

In the end, Lysenko's politically inspired purge of Mendelian genetics backfired, and in the early 1960s prominent Soviet physicists began to openly criticize his fraudulent research and behaviour. Yet, as biologist Carl Lindegren points out in his 1966 book, The Cold War in Biology, much of the criticism of Lysenko emphasized the 'correctness' of Mendelism and the 'incorrectness' of Michurinism, rather than the more overarching 'wrongness' of using his political influence to silence his scientific opponents (Lindegren, 1966). Lysenko was a tyrant who used politics and public popularity to suppress free scientific thinking and those who opposed him. The history of Lysenkoism and its devastating effect on Soviet research stands as a warning to those who argue that scientific research ought to answer to public opinion or political decisions.

\section{CONFLICT OF INTEREST}

The authors declare that they have no conflict of interest.

\section{REFERENCES}

Darlington CD (1977) Obituary-TD Lysenko. Nature 266: 287-288

Graham LR (1987) Genetics. In Science,

Philosophy and Human Behavior in the Soviet Union, pp130-150. New York: Columbia University Press

Hagemann R (2002) How did German genetics avoid Lysenkoism. Trends Genet 18: 320-324

Lindegren CC (1966) Michurinism as a biological phylosophy. In The Cold War in Biology, p55. Ann Arbor MI, USA: Planarian Press Inc.

Liu Y-S (2006) The historical and modern genetics of plant graft hybridization. Adv Genet 56: 101-129

Lysenko TD (1954) Agrobiology. Moscow, Russia: Foreign Languages Publishing House

Ohta Y (1991) Graft-transformation, the mechanism for graft-induced genetic changes in higher plants. Euphytica 55: 91-99

Rossianov KO (1993) Editing Nature: Joseph Stalin and the "new" Soviet biology. ISIS 84: 728-745

Soyfer VN (2001) The consequences of political dictatorship for Russian science. Nat Rev Genet 2: 723-729

Stegemann S, Bock R (2009) Exchange of genetic material between cells in plant tissue grafts. Science 324: 649-651

\section{Yongsheng Liu, Baoyin Li \& Qinglian Wang are at the Henan Institute of Science and Technology in Xinxiang, China. E-mail:ysliu63@yahoo.ca \\ doi:10.1038/embor.2009.198}

